\title{
Synthesis, photophysical and preliminary investigation of the dye-sensitized solar cells properties of functionalized anthracenyl-based bipyridyl and phenanthrolyl Ru(II) complexes
}

\author{
ADEWALE O ADELOYE ${ }^{\mathrm{a}}$, PETER A AJIBADE ${ }^{\mathrm{a}, *}$, FRANCES R CUMMINGS $^{\mathrm{b}}$, \\ LUKAS J LE ROUX ${ }^{b}$, SAMPSON N MAMPHWELI ${ }^{c}$ and EDSON L MEYER ${ }^{c}$ \\ ${ }^{a}$ Department of Chemistry, Faculty of Science and Agriculture, University of Fort Hare, \\ PMB X1314, Alice 5700, South Africa \\ ${ }^{\mathrm{b}}$ CSIR Materials Science and Manufacturing, PO Box 395, Pretoria 0001, South Africa \\ ${ }^{\mathrm{c}}$ Fort Hare Institute of Technology, University of Fort Hare, PMB X1314, Alice 5700, South Africa \\ e-mail: pajibade@ufh.ac.za
}

MS received 6 December 2011; revised 6 October 2012; accepted 16 November 2012

\begin{abstract}
Four new amphiphilic ligands: 4-(2,3-dimethylacrylic acid)-2,2'-bipyridine ( $\left.\mathrm{L}_{1}\right)$, 4-(9-anthracenyl10-(2,3-dimethylacrylic acid)-2,2'-bipyridine $\left(\mathrm{L}_{2}\right), 5$-(2,3-dimethylacrylic acid)-1,10-phenanthroline $\left(\mathrm{L}_{3}\right)$ and 5-(9-anthracenyl-10-(2,3-dimethylacrylic acid)-1,10-phenanthroline $\left(\mathrm{L}_{4}\right)$, with their corresponding homonuclear ruthenium(II) complexes formulated as cis- $\left[\mathrm{Ru}-\left(\mathrm{L}_{1}\right)_{3}\left(\mathrm{PF}_{6}\right)_{2}\right](\mathbf{C 1})$, cis- $\left[\mathrm{Ru}-\left(\mathrm{L}_{2}\right)_{3}\left(\mathrm{PF}_{6}\right)_{2}\right](\mathbf{C 2})$, cis- $[\mathrm{Ru}-$ $\left.\left(\mathrm{L}_{3}\right)_{3}\left(\mathrm{PF}_{6}\right)_{2}\right](\mathbf{C 3})$ and cis-[Ru- $\left.\left(\mathrm{L}_{4}\right)_{3}\left(\mathrm{PF}_{6}\right)_{2}\right](\mathbf{C 4})$, have been synthesized and characterized by elemental analysis, ${ }^{1} \mathrm{H}$ - and ${ }^{13} \mathrm{C}$ - NMR, FT-IR, UV-Vis and photoluminescence spectroscopy. The complexes exhibit broad and intense metal-to-ligand charge transfer (MLCT) transition bands in the visible region (400-700 nm), and red light emitting properties at room temperature. By comparison however, complexes $\mathbf{C 1}$ and $\mathbf{C 2}$ bipyridine moiety gave lower molar absorptivity coefficient at relatively similar wavelength characteristics $(410-520 \mathrm{~nm})$ when compared to $\mathbf{C 3}$ and $\mathbf{C 4}$ with phenanthroline based molecules. Cyclic voltammograms of the complexes revealed complex $\mathbf{C 4}$ with most reduction potential which might be due to increase in the conjugation of the anthracene functionalized units. Preliminary investigation of the solar cell efficiency of the complexes on $\mathrm{TiO}_{2}$ nanocrystalline films gave the best result with efficiency of $0.103 \%$ for $\mathbf{C 1}$ under illumination at $1000 \mathrm{~W} / \mathrm{m}^{2}$ AM 1.5. Electrochemical impedance spectroscopy (EIS) technique however, revealed the charge transfer resistances $\left(\mathrm{R}_{\mathrm{ct}}\right)$ of the electrons on the $\mathrm{TiO}_{2}$ semiconductor.
\end{abstract}

Keywords. Ruthenium(II), polypyridyl ligands, spectroscopy, electrochemistry, DSSCs

\section{Introduction}

The quest for new materials that efficiently harvest solar light continues to be an important goal. Recently, considerable efforts have been focused on new photosensitizers, including ruthenium complexes ${ }^{1-10}$ and organic dyes, ${ }^{11-14}$ in dye-sensitized solar cells (DSSCs) since cis-dithiocyanato bis $\left(4,4^{\prime}\right.$-dicarboxy$2,2^{\prime}$-bipyridine) ruthenium(II) [Ru(dcbpy $\left.)_{2}(\mathrm{NCS})_{2}\right]$ anchored on porous nanocrystalline $\mathrm{TiO}_{2}$ electrode has exhibited $10 \%$ light-to-electric power conversion efficiency. It has been shown that one of the best way to enhance both the absorption coefficient and red-shift of the metal-to ligand charge transfer (MLCT) band in a ruthenium-based photosensitizer was to extend the $\pi$-conjugation length of the colorant's ancillary ${ }^{15}$ or

*For correspondence anchoring ${ }^{16}$ ligands. Other classes of ligands such as carboxylated terpyridine and phenanthroline showed enhanced UV-Vis absorption over a broad range due to their large conjugated backbone structure. These ligands can be utilized as efficient light harvesting sensitizers as well. ${ }^{17}$

The quest for new and alternative approaches for easy building and organizing various photoactive partners around photoactive metals is a developing field of research. ${ }^{18}$ Some authors reported the synthesis of heteroleptic ruthenium complexes by extending the conjugation length of the ancillary ligand. ${ }^{19}$ Such heteroleptic ruthenium complexes have a strong MLCT band and dye solar cells devices based on them display very good photovoltaic performance. In spite of this, the main drawback of these sensitizers is the lack of absorption in the red region of the visible spectrum and also relatively low molar extinction coefficient. ${ }^{20}$ Many researchers have tried to overcome these shortcomings 
without significant success. ${ }^{21-24}$ The molecular engineering of ruthenium complexes for $\mathrm{TiO}_{2}$-based solar cells presents a challenging task as several stringent requirements have to be fulfilled by the sensitizer. ${ }^{25}$ 1,10-Phenanthroline and 2,2'-bipyridine has been used extensively as ligands form metal complexes for various applications such as fluorescence probes, ${ }^{26-29}$ electrocatalyst, ${ }^{30}$ for dyes sensitized solar cells. ${ }^{31}$

The emphasis of the present work is the synthesis of four new ruthenium(II) bipyridyl and phenanthrolyl complexes incorporating anthracenyl units on the complexes thus showing the effect of increasing conjugation length of complexes through ligand substitution. We present here the synthetic methodology, photophysical characterization, spectroscopic, electrochemistry and preliminary solar cell properties of the complexes.

\section{Experimental}

\subsection{Materials and general physicochemical measurements}

All commercial reagents used were analytically pure and used without further purification. The starting material, 4'-Bromo-2,2'-bipyridine was synthesized as described in the literature. ${ }^{32}$ The ligands, $\mathrm{L}_{1}=$ 4-(2,3-dimethylacrylic acid)-2,2'-bipyridine, $\mathrm{L}_{2}=$ 4-(9-anthracenyl-10-(2,3-dimethylacrylic acid)-2,2'bipyridine, $\mathrm{L}_{3}=5$-(2,3-dimethylacrylic acid)-1,10phenanthroline and $\mathrm{L}_{4}=5$-(9-anthracenyl-10-(2,3dimethylacrylic acid)-1,10-phenanthroline, with their corresponding homonuclear ruthenium(II) complexes formulated as cis-[Ru- $\left.\left(\mathrm{L}_{1}\right)_{3}\left(\mathrm{PF}_{6}\right)_{2}\right] \quad$ (C1), cis-[Ru$\left.\left(\mathrm{L}_{2}\right)_{3}\left(\mathrm{PF}_{6}\right)_{2}\right] \quad(\mathbf{C 2})$, cis- $\left[\mathrm{Ru}-\left(\mathrm{L}_{3}\right)_{3}\left(\mathrm{PF}_{6}\right)_{2}\right] \quad$ (C3) and cis- $\left[\mathrm{Ru}-\left(\mathrm{L}_{4}\right)_{3}\left(\mathrm{PF}_{6}\right)_{2}\right](\mathbf{C 4})$, were synthesized with modifications to the reported procedure (scheme 1). ${ }^{33,34}$ All thin-layer chromatography (TLC) analyses were done with aluminium sheets pre-coated with normal phase silica gel 60 F254 (Merck, $0.20 \mathrm{~mm}$ thickness) unless otherwise stated. Gel filtration was performed using Sephadex LH-20 previously swollen in specified solvents prior to loading of extract onto the column
$(3.5 \mathrm{~cm} \times 8.5 \mathrm{~cm})$. Melting points were determined using a Gallenkamp electrothermal melting point apparatus. Microanalyses were carried out with a Fisons elemental analyzer and infrared spectra were obtained as $\mathrm{KBr}$ discs on a Perkin Elmer System 2000 FT-IR and Bruker Tensor 27 spectrophotometer. UV-Vis absorption and fluorescence spectra were recorded in a $1 \mathrm{~cm}$ path length quartz cell on a Perkin Elmer Lambda 35 spectrophotometer and Perkin Elmer Lambda 45 spectrofluorimeter, respectively. ${ }^{1} \mathrm{H}$ - and ${ }^{13} \mathrm{C}$-Nuclear Magnetic Resonance (NMR) spectra were run on a Bruker EMX $400 \mathrm{MHz}$ spectrometer for ${ }^{1} \mathrm{H}$ and $100 \mathrm{MHz}$ for ${ }^{13} \mathrm{C}$. The chemical shift values were reported in parts per million (ppm) relative to (TMS) as internal standard. Chemical shifts were also reported with respect to DMSO $d_{6}$ at $\delta \mathrm{c} 40.98$ and DMSO $\mathrm{d}_{6}$ at $\delta_{\mathrm{H}} 2.50$ or $\mathrm{CDCl}_{3}$ at $\delta_{\mathrm{C}} 77.30$ and $\delta_{\mathrm{H}} 7.24$ for synthesized ligands and complexes. All electrochemical experiments were performed using Autolab potentiostat PGSTAT 302 (EcoChemie, Utrecht, The Netherlands) driven by the general purpose Electrochemical System Data Processing Software (GPES, software version 4.9). A conventional three-electrode system was used. The working electrode was a bare glassy carbon electrode (GCE), $\mathrm{Ag} \mid \mathrm{AgCl}$ wire and platinum wire was used as the pseudo reference and auxiliary electrodes, respectively. The potential response of the $\mathrm{Ag} \mid \mathrm{AgCl}$ pseudo-reference electrode was less than the $\mathrm{Ag} \mid \mathrm{AgCl}$ ( $3 \mathrm{M} \mathrm{KCl}$ ) by $0.015 \pm 0.003 \mathrm{~V}$. Prior to use, the electrode surface was polished with alumina on a Buehler felt pad and rinsed with excess millipore water. All electrochemical experiments were performed in freshly distilled dry DMF containing $\mathrm{TBABF}_{4}$ as supporting electrolyte.

\subsection{Dye-sensitized solar cell fabrication and photo-response measurement}

The preparation and measurement of I-V curves of sandwiched solar cells are as follows. The dye solutions were prepared in the concentration range of $2-3 \times 10^{-4} \mathrm{M}$ in dimethylformamide and a commercially made $\mathrm{TiO}_{2}$ nanocrystalline from Solaronix was

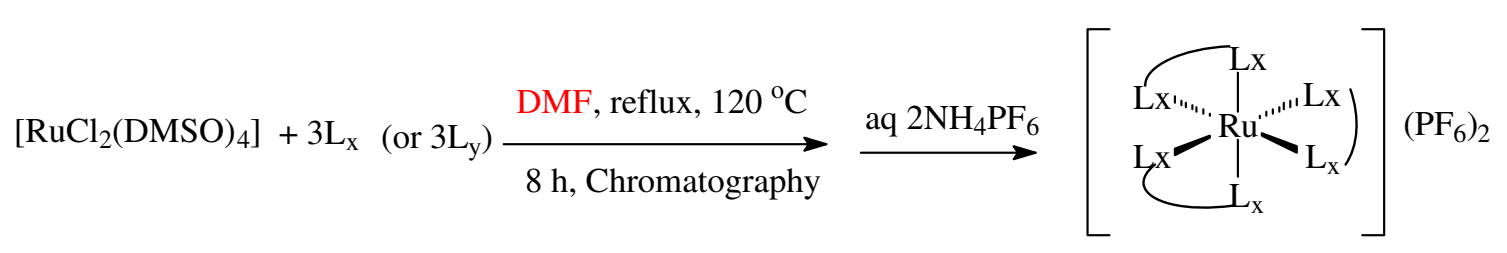

Scheme 1. General synthetic procedure for $\mathbf{C} 1-\mathbf{C} 4$ complexes. $\mathrm{L}_{x}$ or $\mathrm{L}_{y}=$ functionalized bipyridine or phenanthroline ligands. 
dipped into the dye solution for $14-16 \mathrm{~h}$ at room temperature. The dye-coated electrodes were rinsed with ethanol and used as such for photovoltaic measurements. The dye deposited film is used as a working electrode. A sandwich cell was prepared with a second conducting glass coated with chemically deposited platinum from $0.05 \mathrm{M}$ hexachloroplatinic acid. The platinum coated counter electrode and the dye coated $\mathrm{TiO}_{2}$ film of surlyn polymer frame (Dupont) were tightly held using a pressure hot filler to seal the two electrodes. A thin-layer of electrolyte consisting of $0.6 \mathrm{M} \mathrm{BMII}$; $0.05 \mathrm{M} \mathrm{I}_{2} ; 0.1 \mathrm{M} \mathrm{LiI} ; 0.5 \mathrm{M}$ tert-butyl pyridine in $1: 1$ acetonitrile and valeronitrile was introduced into inter electrode space from the counter electrode side through pre-drilled holes. The drilled holes were sealed with cellophane tape. Photo-electrochemical data were measured using a $450 \mathrm{~W}$ Xenon light source that was focused to give $1000 \mathrm{~W} / \mathrm{m}^{2}$ (the equivalent of one sun at air mass 1.5) at the surface of the test cell. The applied potential and measured cell current were measured using a Keithley model 2400 digital sources meter. The current-voltage characteristics of the cell under these conditions were determined by biasing the cell externally and measuring the generated photocurrent. The process was fully automated using Wavemetrics software.

Further, impedance analysis was carried out with the objective to investigate the overall internal resistance of the cell which in turn influences the cell performance. Nyquist plot in between $Z_{\text {real }}$ and $Z_{\text {imag }}$ impedance was recorded with the Autolab FRA equipment using a $10 \mathrm{mV}$ rms sinusoidal modulation.

\subsection{Synthesis of ligands $L_{1}-L_{4}$ and their corresponding $R u(I I)$ bis-hexaflurophosphate complexes}

2.3a Synthesis of 4-(2,3-dimethylacrylic acid)-2,2'bipyridine $\left(L_{1}\right)$ : 4-Bromo-2,2'-bpy (1.05 g, $\left.3.38 \mathrm{mmol}\right)$ and 2,3-dimethylacrylic acid (DMAA) (0.34 g, $3.38 \mathrm{mmol})$ were dissolved in $\mathrm{MeOH}(40 \mathrm{~mL})$ in a $250 \mathrm{~mL}$ flask. Triethylamine $\left(\mathrm{Et}_{3} \mathrm{~N}\right)(1.0 \mathrm{~mL}$ and palladium-carbide $(0.050 \mathrm{~g})$ were added and the mixture was reflux for $8 \mathrm{~h}$ at a temperature between 110 and $120^{\circ} \mathrm{C}$. The reaction was allowed to cool to room temperature and the solvent removed under reduced pressure. The residue was dissolved in degassed water and then extracted with chloroform. The chloroform extract was concentrated in vacuo to obtain a brilliant colourless liquid which solidified after $48 \mathrm{~h}$ at room temperature. The resultant residue was recrystallized in $\mathrm{Et}_{2} \mathrm{O}(30 \mathrm{~mL})$. Colour: white crystalline solid; melting point: ND; IR (KBr): 3054, 2927, 2676, 1965, 1690, 1648, 1581, 1559, 1456, 1419, 1346, 1251, 1141, 1089, 1040, 992, 893, 757, 653, 631, 619, 555. ${ }^{1} \mathrm{H}$ NMR $\left(400 \mathrm{MHz}, \mathrm{DMSO}-\mathrm{d}_{6}\right): \delta 8.66(\mathrm{~d}, J=4.0 \mathrm{~Hz}), 8.41(\mathrm{~d}$, $J=8.0 \mathrm{~Hz}), 7.86(\mathrm{dd}, J=7.6,8.0 \mathrm{~Hz}), 7.36(\mathrm{dd}, J=$ 5.2, 7.2 Hz), $1.73\left(\mathrm{~s}, \mathrm{CH}_{3}\right), 1.66\left(\mathrm{~d}, \mathrm{CH}_{3}\right) .{ }^{13} \mathrm{C} \mathrm{NMR}$ $\left(400 \mathrm{MHz}\right.$, DMSO-d $\left.\mathrm{d}_{6}\right): \delta 169.76,156.21,149.98$, 137.86, 136.88, 129.74, 124.81, 121.32, 14.81, 12.71. Elemental Analysis: Found: C 70.71, H 5.55, N 11.31; required $\mathrm{C}_{15} \mathrm{H}_{14} \mathrm{~N}_{2} \mathrm{O}_{2}$ : Calculated: $\mathrm{C} 70.85, \mathrm{H} 5.55, \mathrm{~N}$ 11.02. Percentage yield: $0.90 \mathrm{~g}, 67 \%$.

2.3b Synthesis of 4-(9-anthracenyl-10-(2,3-dimethylacrylic acid)-2,2'-bipyridine $\left(L_{2}\right)$ : 4-Bromo-2,2'-bpy $(1.00 \mathrm{~g}, 4.82 \mathrm{mmol})$ and 9-bromo-10-(2,3-dimethylacrylic acid)-anthracene (1.72 g, $4.82 \mathrm{mmol})$ were dissolved in benzene-dichloromethane $(50 \mathrm{~mL}, \mathrm{v} / \mathrm{v}, 1: 1)$, followed by the addition of $\mathrm{Et}_{3} \mathrm{~N}(1 \mathrm{~mL}), \mathrm{KOH}$ and palladium-carbide $(0.05 \mathrm{~g})$. The reaction was carried out under reflux for $12 \mathrm{~h}$ at temperature $110-120^{\circ} \mathrm{C}$. Purification and isolation of the product followed as reported for $\mathrm{L}_{1}$ above. Colour: Yellow crystalline solid; Melting point: $167-169^{\circ} \mathrm{C}$; IR (KBr): $3427,3056,2926$, 1952, 1802, 1690, 1622, 1582, 1558, 1524, 1456, 1437, 1420, 1349, 1304, 1256, 1162, 1149, 1089, 1040, 1028, 995, 926, 747, 676, 654, 619, 605, 578. ${ }^{1} \mathrm{H}$ NMR $\left(400 \mathrm{MHz}, \mathrm{DMSO}-\mathrm{d}_{6}\right): \delta 9.20(2 \mathrm{~d}, J=1.6,4.4 \mathrm{~Hz})$, $8.57(\mathrm{dd}, J=3.2,6.8 \mathrm{~Hz}), 8.26(\mathrm{~d}, J=2.0 \mathrm{~Hz}), 8.24$ $(\mathrm{d}, J=1.6 \mathrm{~Hz}), 7.62(\mathrm{dd}, J=3.2 .6 .8 \mathrm{~Hz}), 2.17$ (s, $\left.\mathrm{CH}_{3}\right), 1.67\left(\mathrm{~s}, \mathrm{CH}_{3}\right) .{ }^{13} \mathrm{CNMR}(400 \mathrm{MHz}, \mathrm{DMSO}-$ $\left.\mathrm{d}_{6}\right): \delta 156.76,150.31,146.27,144.21,135.94,131.03$, $128.52,128.25,127.44,126.49,124.21,123.51$, 123.04, 30.90 and 21.92. Elemental Analysis: Found: C 80.71, H 5.55, N 6.31; required $\mathrm{C}_{29} \mathrm{H}_{22} \mathrm{~N}_{2} \mathrm{O}_{2}$ : Calculated: C 80.91, H 5.15, N 6.51. Percentage yield: 1.93 g, $71 \%$.

2.3c Synthesis of 5-(2,3-DMAA)-1,10-phenanthroline $\left(L_{3}\right)$ : The method of synthesis followed was as described for $\mathrm{L}_{1}$ (section 2.3a). 5-Bromo1,10-phenanthroline $(1.00 \mathrm{~g}, 3.86 \mathrm{mmol})$ and $2,3-$ dimethylacrylic acid $(0.39 \mathrm{~g}, 3.86 \mathrm{mmol})$ were dissolved in $\mathrm{MeOH}(40 \mathrm{~mL})$ in a $250 \mathrm{~mL}$ flask. $\mathrm{Et}_{3} \mathrm{~N}$ $(1.0 \mathrm{~mL})$ and palladium-carbide $(0.050 \mathrm{~g})$ were added and the mixture was refluxed for $14 \mathrm{~h}$ between 110 and $120^{\circ} \mathrm{C}$. The product of reaction was recrystallized in $\mathrm{Et}_{2} \mathrm{O}$. Colour: White-pink crystalline solid, melting point: ND, IR (KBr): 3419, 3032, 2929, 1694, 1652, $1619,1589,1561,1506,1420,1385,1343,1256,1219$, 1140, 1093, 1080, 1037, 1015, 843, 766, 734, 769, 625, 530; ${ }^{1} \mathrm{H}$ NMR $\left(400 \mathrm{MHz}, \mathrm{CDCl}_{3}\right): \delta 11.32(\mathrm{br}, \mathrm{OH})$, 8.97 (t, 2H, H-2, 9), 7.92 (t, 2H, H-3, 8), 7.91 (s, 1H, 
H-6), 7.44 (d, 1H, H-4), 6.82 (d, 1H, H-7), 1.67 (s, $\left.\mathrm{CH}_{3}\right), 1.58\left(\mathrm{~d}, \mathrm{CH}_{3}\right) ;{ }^{13} \mathrm{C}$ NMR $\left(400 \mathrm{MHz}, \mathrm{CDCl}_{3}\right)$ : $\delta 150.39,150.30,146.30,146.21,138.79,136.13$, $128.81,128.72,126.68,126.59,123.27,123.19,14.74$, and 12.14; Elemental Analysis: Found: $\mathrm{C}$ 73.65, $\mathrm{H}$ 5.11, N 10.19; required $\mathrm{C}_{17} \mathrm{H}_{14} \mathrm{~N}_{2} \mathrm{O}_{2}$ : Calculated: $\mathrm{C}$ 73.37, H 5.07, N 10.07. Percentage yield: 0.74 g, $53 \%$.

2.3d Synthesis of 5-(9-anthracenyl-10-(2,3dimethylacrylic acid)-1,10-phenanthroline (L4): The method of synthesis followed was as described for $\mathrm{L}_{2}$ (section 2.3a). 5-Bromo-1,10-phenanthroline (1.0 g, $3.86 \mathrm{mmol})$ and 9-bromo-10-(2,3-dimethylacrylic acid)-anthracene (1.37 g, $3.86 \mathrm{mmol})$ were dissolved in benzene-dichloromethane $(70 \mathrm{~mL}, \mathrm{v} / \mathrm{v}, 1: 1)$, followed by the addition of $\mathrm{Et}_{3} \mathrm{~N}(1 \mathrm{~mL}), \mathrm{KOH}$ and palladiumcarbide $(0.05 \mathrm{~g})$. The reaction was carried out under reflux for $12 \mathrm{~h}$ at temperature $110-120^{\circ} \mathrm{C}$. Isolation and purification of the residue was followed as reported in section 2.3b. Colour: yellow crystalline solid; melting point: $167-169^{\circ} \mathrm{C}$; IR (KBr): 3427, 3055, 2979, 2924 , 2552, 1966, 1871, 1802, 1579, 1558, 1453, 1417, 1304, 1255, 1140, 1089, 1040, 994, 926, 756, 654, 619, 579; ${ }^{1} \mathrm{H} \mathrm{NMR}\left(\mathrm{CDCl}_{3}\right): \delta 9.18(\mathrm{~d}, J=3.2 \mathrm{~Hz}), 8.23(\mathrm{~d}, J=$ $7.2 \mathrm{~Hz}), 7.77$ (s), $7.62(\mathrm{dd}, J=4.4,8.0 \mathrm{~Hz}), 6.97(\mathrm{~d}$, $J=7.2 \mathrm{~Hz}), 1.81\left(\mathrm{t}, \mathrm{CH}_{3}\right), 1.23\left(\mathrm{t}, \mathrm{CH}_{3}\right) ;{ }^{13} \mathrm{C} \mathrm{NMR}$ $\left(\mathrm{CDCl}_{3}\right): 150.28,146.19,139.25,135.97,128.61$, 126.49, 123.06, 14.42, 11.74. Elemental Analysis: Found: C 81.75, H 4.62, N 6.33; required $\mathrm{C}_{31} \mathrm{H}_{22} \mathrm{~N}_{2} \mathrm{O}_{2}$ : Calculated: C 81.92, H 4.88, N 6.16; Percentage yield: $1.40 \mathrm{~g}, 59 \%$.

2.3e Synthesis of tris-(4-(2,3-dimethylacrylic acid)2,2'-bipyridyl-ruthenium(II) bis-hexafluorophosphate complex (C1): In a $250 \mathrm{~mL}$ flask, $\left[\mathrm{RuCl}_{2}(\mathrm{DMSO})_{4}\right]$ $(0.05 \mathrm{~g}, 1.03 \mathrm{mmol})$ was dissolved in $N, N$-dimethylformamide followed by the addition of ligand $\mathrm{L}_{1}$ $(0.08 \mathrm{~g}, 3.09 \mathrm{mmol})$. The mixture was refluxed at $120^{\circ} \mathrm{C}$ for $5 \mathrm{~h}$ in the dark. The solution was allowed to cool to room temperature and filtered to remove unreacted starting material. The filtrate was concentrated to dryness and $40 \mathrm{~mL}$ of $0.05 \mathrm{M} \mathrm{NaOH}$ solution was added to give dirty brown precipitate which was filtered off. The $\mathrm{pH}$ of the resulting solution was adjusted to 3 with $0.5 \mathrm{M} \mathrm{HNO}_{3}$. The solution was left to stand in the fridge $\left(-2^{\circ} \mathrm{C}\right)$ for $12 \mathrm{~h}$ before being filtered and concentrated in vacuo. Aqueous solution of $\mathrm{NH}_{4} \mathrm{PF}_{6}$ was added to precipitate the residue from the bulk, and then filtered. The crude residue product was adsorbed onto Sephadex LH-20 adsorbent in a glass column and eluted using solvent system D (chloroform-methanol, $50 \%, 250 \mathrm{~mL}$ ). ${ }^{35}$ Colour: Dark brown solid; melting point: $201-204^{\circ} \mathrm{C}$; IR (KBr) vmax/cm-1: 3430, 2926 , 2855, 1622, 1607, 1497, 1464, 1446, 1424, 1385, 1314, $1270,1245,1162,1125,1070,838,763,731,610,557$, 472, 421; UV-Vis $\left(\lambda_{\max } / \mathrm{nm}, \varepsilon=\mathrm{M}^{-1} \mathrm{~cm}^{-1}, \mathrm{DMF}\right)$ : 343 (2059), 447 (3218), 914 (880) and 1015 (1200); Emission wavelength: $\left(\lambda_{\text {exc }}=470 \mathrm{~nm}, \lambda_{\text {em }}=747 \mathrm{~nm}\right)$. ${ }^{1} \mathrm{H}$ NMR $\left(\right.$ DMSO- $\left._{6}\right): \delta 8.62(\mathrm{~d}, J=5.6 \mathrm{~Hz}, 1 \mathrm{H}), 8.06$ (s, 1H), 7.69 (s, 1H), 7.43 (s, 1H). ${ }^{13} \mathrm{C}$ NMR (DMSO$\left.\mathrm{d}_{6}\right): \delta$ 157.23, 151.82, 128.52, 125.03. Elemental Analysis: Found: C 46.63, H 3.60, N 7.54; required $\mathrm{RuC}_{45} \mathrm{H}_{42} \mathrm{~N}_{6} \mathrm{O}_{6} \mathrm{P}_{2} \mathrm{~F}_{12}$ : Calculated: $\mathrm{C}$ 46.84, $\mathrm{H}$ 3.67, N 7.28. Percentage yield: $0.083 \mathrm{~g}, 64 \%$.

2.3f Synthesis of tris-4-(9-anthracenyl-(2,3-dimethylacrylic acid)-2,2'-bipyridyl-ruthenium(II)-bis-hexafluorophosphate complex (C2): The complex was prepared in a similar manner as described for $\mathbf{C 1}$ above. Ligand $\left(\mathrm{L}_{2}\right)(0.22 \mathrm{~g}, 0.51 \mathrm{mmol})$ and $\left[\mathrm{RuCl}_{2}(\mathrm{DMSO})_{4}\right]$ $(0.08 \mathrm{~g}, 0.17 \mathrm{mmol})$ were added as a mixture and refluxed in DMF $(60 \mathrm{~mL})$. The product was obtained after precipitation from excess aqueous $\mathrm{NH}_{4} \mathrm{PF}_{6}$. Colour: orange solid; melting point: $226-227^{\circ} \mathrm{C}$; IR (KBr): 3430, 3076, 2928, 2865, 1902, 1678, 1622, $1591,1580,1437,1332,1321,1304,1285,1256$, 1206, 1170, 1098, 1028, 969, 937, 926, 809, 747, 694, 622, 604, 579, 387; UV-Vis $\left(\lambda_{\max } / \mathrm{nm}, \varepsilon=\mathrm{M}^{-1} \mathrm{~cm}^{-1}\right.$, DMF): 358 (4342), 379 (4960), 401(5557), 447 (5770), 907 (1410) and 1011 (1970); Emission wavelength: $\left(\lambda_{\text {exc. }}=640 \mathrm{~nm}, \lambda_{\text {em }}=710 \mathrm{~nm}\right)$. Selected ${ }^{1} \mathrm{H}$ NMR data $\left(\mathrm{CDCl}_{3}\right): \delta 8.83(\mathrm{~d}, J=7.6 \mathrm{~Hz}), 8.56(\mathrm{~m}), 8.17(\mathrm{~s})$, 7.74 (s), 7.53 (s); Electrochemical Data: $\mathrm{Ru}^{2+} / \mathrm{Ru}^{3+}=$ $0.64 \mathrm{~V} ; \mathrm{E}_{\text {anodic }}=0.42 \mathrm{~V}, \mathrm{E}_{\text {cathodic }}=-0.99 \mathrm{~V}$. Elemental Analysis: Found. C 62.45, H 3.55, N 4.63; required $\mathrm{RuC}_{87} \mathrm{H}_{66} \mathrm{~N}_{6} \mathrm{O}_{6} \mathrm{P}_{2} \mathrm{~F}_{12}$ : Calculated. C 62.11, H 3.95, N 4.99. Percentage yield: $0.135 \mathrm{~g}, 45 \%$.

2.3g Synthesis of tris-5-(2,3-dimethylacrylic acid)1,10-phenanthroline $R u(I I)$ bis-hexafluorophosphate complex (C3): The complex was prepared in a similar manner as described for $\mathbf{C 1}$ above. Ligand $\mathrm{L}_{3}(0.16 \mathrm{~g}$, $0.58 \mathrm{mmol}),\left[\mathrm{RuCl}_{2}(\mathrm{DMSO})_{4}\right](0.09 \mathrm{~g}, 0.19 \mathrm{mmol})$ were dissolved and refluxed in DMF $(60 \mathrm{~mL})$. A red oily product was obtained after column chromatography $\left(\mathrm{Et}_{2} \mathrm{O}-\mathrm{MeOH}, 50 \%\right)$, and was precipitated by adding excess of aqueous $\mathrm{NH}_{4} \mathrm{PF}_{6}$. Colour: Orange solid; Melting point: $236-239^{\circ} \mathrm{C}$; IR (KBr) $v_{\max } / \mathrm{cm}^{-1}: 3551,3479$, 3414, 3238, 2928, 2852, 1637, 1617, 1428, 1412, 1342, 1256, 1206, 1147, 1095, 1018, 927, 839, 775, 747, 722, 620, 557, 529, 474, 407; UV-Vis $\left(\lambda_{\max } / \mathrm{nm}, \varepsilon=\right.$ $\mathrm{M}^{-1} \mathrm{~cm}^{-1}$, DMF): 421 (12 477), 443 (13 030); Emission wavelength: $\left(\lambda_{\text {exc. }}=470 \mathrm{~nm}, \lambda_{\text {em }}=715 \mathrm{~nm}\right)$; Selected ${ }^{1} \mathrm{H}$ NMR data $\left(\mathrm{CDCl}_{3}\right): \delta 8.75(\mathrm{~d}, J=8.4 \mathrm{~Hz})$, 
$8.36(\mathrm{~s}), 8.06(\mathrm{~d}, J=5.2 \mathrm{~Hz}), 7.74(\mathrm{dd}, J=5.2$, $8.4 \mathrm{~Hz}), 6.71(\mathrm{~d}, J=6.8 \mathrm{~Hz}), 2.06\left(\mathrm{~s}, \mathrm{CH}_{3}\right), 1.71$ $\left(\mathrm{m}, \mathrm{CH}_{3}\right)$; Electrochemical Data: $\mathrm{Ru}^{2+} / \mathrm{Ru}^{3+}=0.84 \mathrm{~V}$, $\mathrm{E}_{1 / 2}=0.15 \mathrm{~V}, 0.47 \mathrm{~V}$. Elemental Analysis: Found: C 50.01, H 3.55, N 6.48; required $\mathrm{RuC}_{51} \mathrm{H}_{42} \mathrm{~N}_{6} \mathrm{O}_{6} \mathrm{P}_{2} \mathrm{~F}_{12}$ : Calculated: C 49.97, H 3.45, N 6.86. Percentage yield: $0.13 \mathrm{~g}, 53 \%$.

2.3h Synthesis of tris-5-(9-(anthracenyl-(2,3-dimethylacrylic acid)-1,10-phenanthroline ruthenium(II) bishexafluorophosphate complex (C4): The complex was prepared in a similar manner as described for $\mathbf{C 1}$ above. Ligand $\mathrm{L}_{4}(0.10 \mathrm{~g}, 0.22 \mathrm{mmol})$ and $\left[\mathrm{RuCl}_{2}(\mathrm{DMSO})_{4}\right]$ $(0.04 \mathrm{~g}, 0.07 \mathrm{mmol})$ were dissolved in $\mathrm{DMF} / \mathrm{MeOH}$ $(60 \mathrm{~mL}, 1: 1, \mathrm{v} / \mathrm{v})$ and refluxed. The product was precipitated by adding excess aqueous $\mathrm{NH}_{4} \mathrm{PF}_{6}$. Colour: Dark orange solid; Melting point: $>300^{\circ} \mathrm{C}$; IR $(\mathrm{KBr})$ $v_{\max } / \mathrm{cm}^{-1}: 3550,3474,3414,2926,1638,1617,1464$, 1447, 1309, 1256, 1162, 1028, 926, 838, 761, 747, 731, 620, 578, 557, 475; UV-Vis $\left(\lambda_{\max } / \mathrm{nm}, \varepsilon=\mathrm{M}^{-1} \mathrm{~cm}^{-1}\right.$ DMF): 343 (9230), 362 (12330), 383 (17096), 405 (18240), 452 (11556); Emission wavelength: $\left(\lambda_{\mathrm{exc}}=\right.$ $\left.470 \mathrm{~nm}, \lambda_{\mathrm{em}}=676 \mathrm{~nm}\right)$. Selected ${ }^{1} \mathrm{H}$ NMR data $\left(\mathrm{CDCl}_{3}\right): \delta 8.83(\mathrm{~d}, J=8.0 \mathrm{~Hz}), 8.56(\mathrm{dd}, J=3.2$, $6.8 \mathrm{~Hz}), 8.17(\mathrm{t}), 7.82(\mathrm{dt}, J=3.2,6.8 \mathrm{~Hz}), 7.73(\mathrm{~d}$, $J=5.6 \mathrm{~Hz}), 7.53(\mathrm{dd}, J=6.0,6.4 \mathrm{~Hz}) ;{ }^{13} \mathrm{C} \mathrm{NMR}$ $\left(\mathrm{CDCl}_{3}\right): \delta 157.42,152.07,138.79,131.26,128.75$, 125.34, 13.94; Electrochemical Data: $\mathrm{E}_{\text {anodic }}=0.43 \mathrm{~V}$, $\mathrm{Ru}^{2+} / \mathrm{Ru}^{3+}=0.71 \mathrm{~V} ; \mathrm{E}_{1 / 2}=-0.58 \mathrm{~V}$. Elemental Analysis: Found: $\mathrm{C}$ 64.01, H 4.11, N 4.23; required $\mathrm{RuC}_{93} \mathrm{H}_{66} \mathrm{~N}_{6} \mathrm{O}_{6} \mathrm{P}_{2} \mathrm{~F}_{12}$ : Calculated: C 63.66, H 3.79, N 4.79. Percentage yield: $0.08 \mathrm{~g}, 60 \%$.

\section{Results and discussion}

\subsection{Synthesis of ligands and complexes}

Functionalized anthracene, 2,2'-bipyridine and 1,10phenanthroline derivatives were synthesized according to established procedure. ${ }^{32}$ The initial aromatic substitution of one of the bromide ion on 9,10dibromoanthracene with 2,3-dimethylacrylic acid was successful due to the fact that we were able to find a satisfactory solvent system combination $(50 \%$, dichloromethane-benzene), to overcome the poor solubility property of 9,10-dibromoanthracene in common organic solvents. ${ }^{35}$ The synthesis of the metal precursor $\left[\mathrm{RuCl}_{2}(\mathrm{DMSO})_{4}\right]$ and all the complexes $\mathbf{C 1}-\mathbf{C 4}$ (figure 1), was carried out by following the general route. ${ }^{33,34}$ The first step was the coordination of the DMSO ligand with $\mathrm{RuCl}_{3} \cdot \mathrm{H}_{2} \mathrm{O}$ followed by the sequential substitution of the DMSO with synthesized ligands (scheme 1). All complexes were purified in column chromatography. However, attempts were not made to isolate the various side product fractions from column chromatography. The major products purity was ascertained using thin-layer chromatography (TLC) in appropriate solvent systems which were then followed by precipitation in aqueous solution of ammonium hexafluorophosphate.

\subsection{Infrared studies of complexes}

The FT-IR spectra of the starting materials, the ligands and the complexes showed certain characteristic absorption bands that were compared and assigned on careful comparison. Due to structural similarities among the various ligands, a strong vibrational band between 3427 and $3419 \mathrm{~cm}^{-1}$ was found. This gave an indication of the presence of an $\mathrm{O}-\mathrm{H}$ group possibly from the carboxylic acid moiety in the ligands. The vibrational frequency bands between 3076 and $3027 \mathrm{~cm}^{-1}$ may be due to the presence of an $\alpha$, $\beta$-unsaturated carboxylic acid and/or aromatic $\mathrm{C}-\mathrm{H}$ stretching characteristics of the molecules. The band at $2928 \mathrm{~cm}^{-1}$ shows the presence of $\mathrm{C}-\mathrm{H}$ stretching of methyl groups. The bands at 1694,1690 , and $1622 \mathrm{~cm}^{-1}$ are due to carbonyl stretching and the aromatic $\mathrm{C}=\mathrm{C}$ stretching band was found in the region of $1621 \mathrm{~cm}^{-1}$. Bands in the region $1581-1502 \mathrm{~cm}^{-1}$ were assigned to the $\mathrm{C}-\mathrm{N}$ stretching of the polypyridyl groups. The strong bands at $1456-1417 \mathrm{~cm}^{-1}$ were assigned to $\mathrm{C}-\mathrm{H}$ deformation of the methyl groups and the presence of ethereal groups $(\mathrm{C}-\mathrm{O})$ in the molecules was confirmed with the bands at $1256,1216 \mathrm{~cm}^{-1}$. At the fingerprint region, the strong peak band at $926 \mathrm{~cm}^{-1}$ was conspicuously absent in those ligands containing no anthracenyl functionalities. This band is indicative of the $\mathrm{C}-\mathrm{C}$ bond linkage between the anthracene and the bipyridine or phenanthroline ligand.

In the FT-IR spectra of the complexes, it was observed that nearly all the complexes showed an upward shift in absorption frequency for the $\mathrm{O}-\mathrm{H}$ stretching vibration at $3550 \mathrm{~cm}^{-1}$. No major change in frequency was observed in the region of 3237$2850 \mathrm{~cm}^{-1}$. Furthermore, peaks in the region 770 and $730 \mathrm{~cm}^{-1}$ demonstrate the existence of four adjacent hydrogen atoms common to the anthracenyl ligands and their corresponding complexes. All vibrational peaks in the region are found relatively weak and broad in the complexes, which may be ascribed to the loss of crystallinity and the broad distribution of the anthracene chain length. ${ }^{36}$ The weak absorption frequencies between 466 and $444 \mathrm{~cm}^{-1}$, respectively, show 


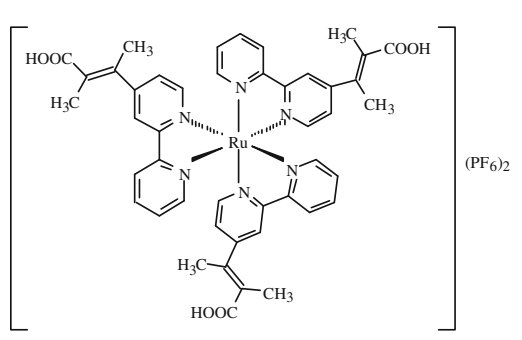

C1

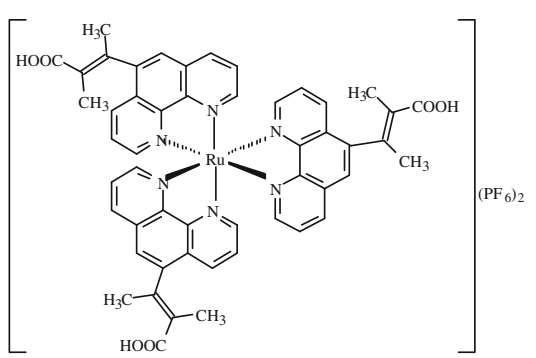

C3

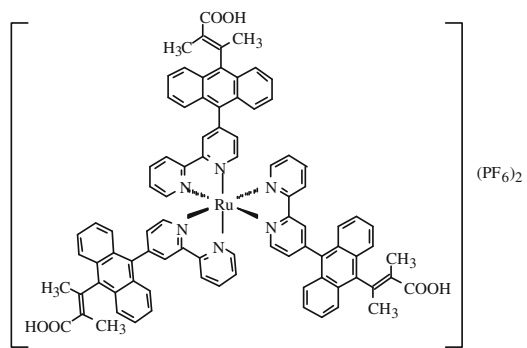

C2

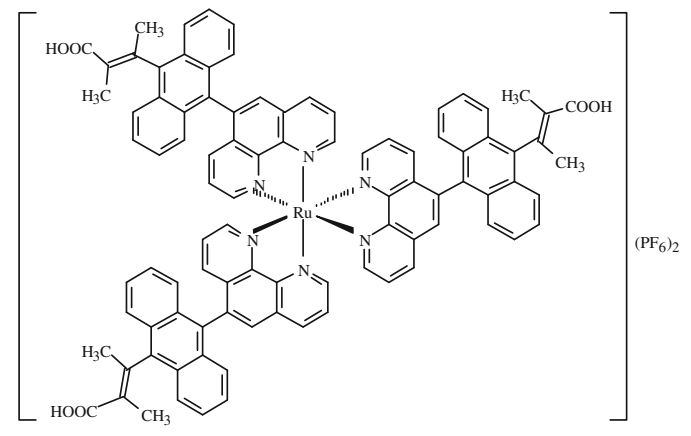

C4

Figure 1. Proposed structures for the complexes.

the coordination of nitrogen atoms of the ancillary ligands to ruthenium central metal atom. ${ }^{37}$

\subsection{Electronic absorption and emission studies of C1-C4 complexes}

The UV-Vis spectra of complexes C1-C4 are shown in figure 2 below. The UV-region, $200-300 \mathrm{~nm}$, contained the $\pi \rightarrow \pi *$ intra ligand absorption for the bipyridyl and phenanthrolyl ligands. This region is not shown here in the spectra. The near-visible region between 350 and $405 \mathrm{~nm}$ was occupied by the vibronic absorption peaks for the substituted anthracene. The vibronic peaks were

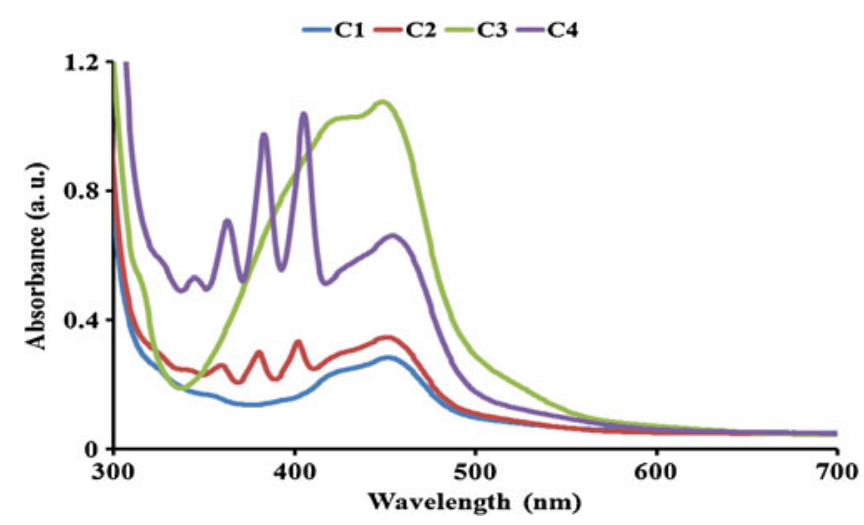

Figure 2. UV-Vis absorption spectra of complexes C1-C4 in DMF. of higher intensity in $\mathbf{C 4}$ for a substituted phenathroline ligand than its counterpart $\mathbf{C 2}$, containing the bipyridyl ligand. The peaks were not found in both $\mathbf{C 1}$ and C3 complexes. At the visible region, $410-520 \mathrm{~nm}$, all the complexes show the metal-to-ligand charge transfer transitions (MLCT) characteristics of a Ru(II) complexes. For the bipyridyl ruthenium(II) complexes (C1 and C2), virtually, the wavelength differ by only $1 \mathrm{~nm}$ (445 and $446 \mathrm{~nm}$ ), respectively, but higher molar extinction coefficient is recorded for $\mathbf{C 2}$. The opposite could be said for the phenanthroline complexes as found in $\mathbf{C 3}$ and $\mathbf{C 4}$. By comparison, complex $\mathbf{C 4}$ absorption maximum wavelength at $452 \mathrm{~nm}$ which is blue-shifted ( $c a=$ $5 \mathrm{~nm}$ ) in $\mathbf{C 3}$.

The emission spectra of the complexes $\mathbf{C 1}, \mathbf{C 2}, \mathbf{C} 3$ and $\mathbf{C 4}$ are shown in figure 3 . It is observed that all the complexes show good photoluminescence properties. However, the information from the spectra shows that towards the near infrared region, emission of the complexes is governed by the molecular weight. $\mathbf{C 1}$ with the smallest molecular weight (863.94 a.u) gave the highest emission wavelength at $748 \mathrm{~nm}$ which is blue-shifted ( $c a=39,33$ and 72) for $\mathbf{C 2}, \mathbf{C 3}$ and $\mathbf{C 4}$, respectively.

\subsection{NMR spectral studies of ligands and complexes}

The proton NMR spectrum of $\mathrm{L}_{1}$ contains six peaks at $8.66(\mathrm{~d}, 1 \mathrm{H}), 8.41(\mathrm{~d}, 1 \mathrm{H}), 7.86(\mathrm{dd}, 1 \mathrm{H}), 7.36$ $(1 \mathrm{H}), 1.73(\mathrm{~s}, 3 \mathrm{H}), 1.66(\mathrm{~d}, 3 \mathrm{H}) \mathrm{ppm}$. The bipyridine 


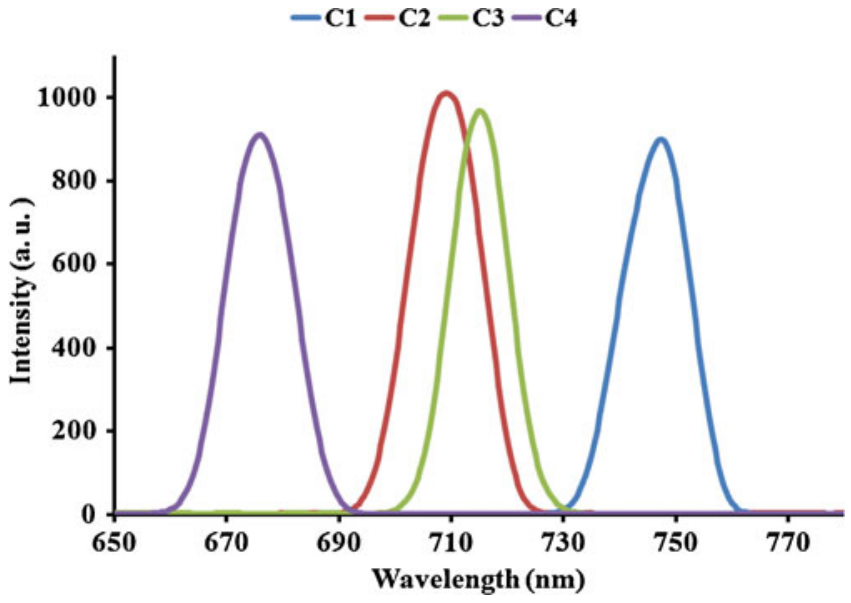

Figure 3. Emission spectra of complexes C1-C4 in DMF.

peak positions are very similar to the starting bromobipyridine material. The principal difference is due to the inclusion of the methyl resonance at the upfield region of the spectrum. The ${ }^{13} \mathrm{C}$ NMR spectrum gave the anticipated peaks at $169.76,156.21,149.98,137.86$, $136.88,129.74,124.81,121.32,14.81$ and 12.71 . The bipyridine peaks due to chemical equivalency were observed in the range of $156-128 \mathrm{ppm}$. The peak at $169.76 \mathrm{ppm}$ was assigned to the carbonyl carbon; the two peaks at 124.81 and 121.32 were assigned to the alkenyl carbons, while the methyl groups were found at 14.81 and $12.71 \mathrm{ppm}$. The proton NMR spectrum of $\mathrm{L}_{2}$ shows five signals at the aromatic region at $\delta 9.20$ (d), 8.57 (dd), 8.26 (d), 8.24 (d), 7.62 (dd) were assigned to the bipyridine and anthracene moieties. The two singlet peaks at the aliphatic region were assigned to the methyl groups at $\delta 2.17$ and $1.67 \mathrm{ppm}$. The ${ }^{13} \mathrm{C}$ spectrum of $\mathrm{L}_{2}$ was similar to that of $\mathrm{L}_{1}$ except those additional peaks at $131.03,128.25,127.44$ and $126.49 \mathrm{ppm}$ that were assigned to the anthracenyl carbons signals. The proton NMR spectrum of $\mathrm{L}_{3}$ is very similar to that obtained for $\mathrm{L}_{1}$, but for ${ }^{13} \mathrm{C}$ NMR that contained two additional carbon peaks of the phenanthroline ligands. In $\mathrm{L}_{4}$, two doublets, one doublet of doublet and a single peak were observed at the aromatic region $(\delta 9.18$ $6.97 \mathrm{ppm})$. These were assigned to $\mathrm{H}-2,9 ; \mathrm{H}-4,7$, and $\mathrm{H}-3,8$, respectively and the singlet peak assigned to $\mathrm{H}-$ 6. However, it was difficult to distinguish those peaks for anthracenyl protons in the spectrum for which a downfield shift $(c a=0.21 \mathrm{ppm})$ was observed when compared to $\mathrm{L}_{3}$.

Complex C1 was purified using Sephadex LH-20 column chromatography and was obtained as a darkbrown solid. The proton NMR spectrum of the complex shows only one doublet peak at $\delta 8.62 \mathrm{ppm}$ and three singlet peaks at $8.06,7.69$ and $7.43 \mathrm{ppm}$ at the aromatic region. When compared to the proton NMR spectrum data of the coordinating ligand $\mathrm{L}_{1}$, all proton peaks experience upfield shifts in the chemical shift values, this is attributed to the effect of the lone pair-lone pair electron donor property of the nitrogen atoms of the bipyridyl rings to the ruthenium metal centre. However, unlike in $\mathrm{L}_{1}$, the aliphatic region of the spectrum is devoid of the presence of the methyl protons chemical shift to signify the presence of the substituent group of the 2,3-dimethylacrylic acid. This result was further corroborated with the absence of the carbonyl and/or methyl peaks in the ${ }^{13} \mathrm{C}$ NMR spectrum. We tend to adduce the loss of these peaks to the fragmentation of 2,3-dimethylacrylic acid possibly during intense heating and/or column chromatography in Sephadex LH20. Due to the poor solubility of $\mathbf{C 2}$ in various organic solvents, an unsatisfactory proton NMR spectrum was obtained and it was difficult to assign individual peaks based on the available data. The proton NMR spectrum of $\mathbf{C} \mathbf{3}$ showed expected peaks for a 5-substituted phenanthroline ligand. In the aromatic region of the spectrum, one doublet of doublet, three doublet peaks and a single peak were observed. The peaks at $\delta 8.75$, 8.06 and $6.71 \mathrm{ppm}$ were assigned to $\mathrm{H}-2,9 ; \mathrm{H}-4$ and $\mathrm{H}-7$ protons. The doublet of doublet peak at $\delta 7.74 \mathrm{ppm}$ was assigned to protons $\mathrm{H}-3,8$. The singlet peaks at $\delta 2.06$ and a multiplet peak at $\delta 1.71$ were assigned to the methyl protons. The proton NMR spectrum of $\mathbf{C 4}$ shows six peaks at $\delta 8.83(\mathrm{~d}, J=8.0 \mathrm{~Hz}), 8.56(\mathrm{dd}$, $J=3.2,6.8 \mathrm{~Hz}), 8.17(\mathrm{t}), 7.82(\mathrm{dt}, J=3.2,6.8 \mathrm{~Hz})$, $7.73(\mathrm{~d}, J=5.6 \mathrm{~Hz})$ and $7.53(\mathrm{dd}, J=6.0,6.4 \mathrm{~Hz})$. The phenanthroline peak positions are very similar to that of C3. The only difference is due to the anthracenyl peaks. The resonances were assigned to the protons on the phenanthroline ligand and those of the anthracene

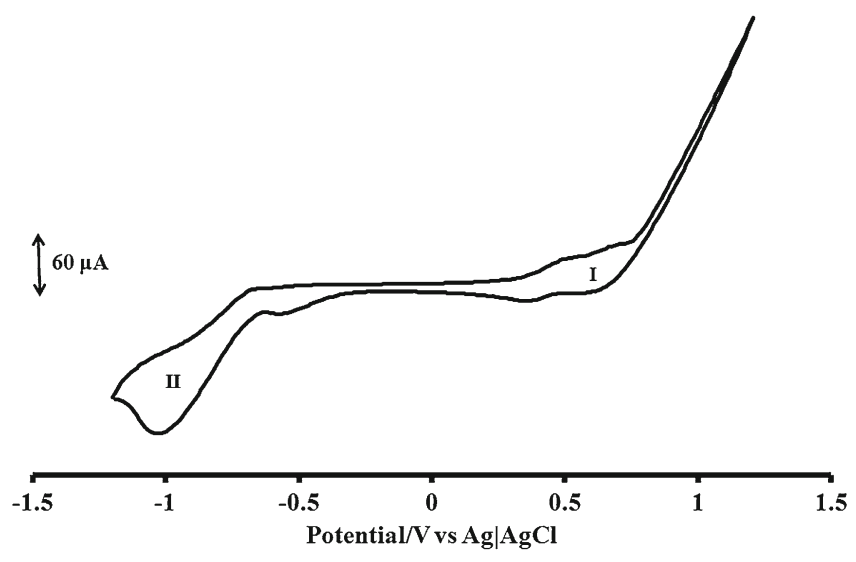

Figure 4. Cyclic voltammogram of $\mathbf{C 2}$ at $1 \times 10^{-3} \mathrm{M}$ in freshly distilled DMF containing $0.1 \mathrm{M} \mathrm{TBABF}_{4}$ as supporting electrolyte. Step potential $=5 \mathrm{mV}$, amplitude $=50 \mathrm{mV}$ vs. $\mathrm{Ag} \mid \mathrm{AgCl}$. 


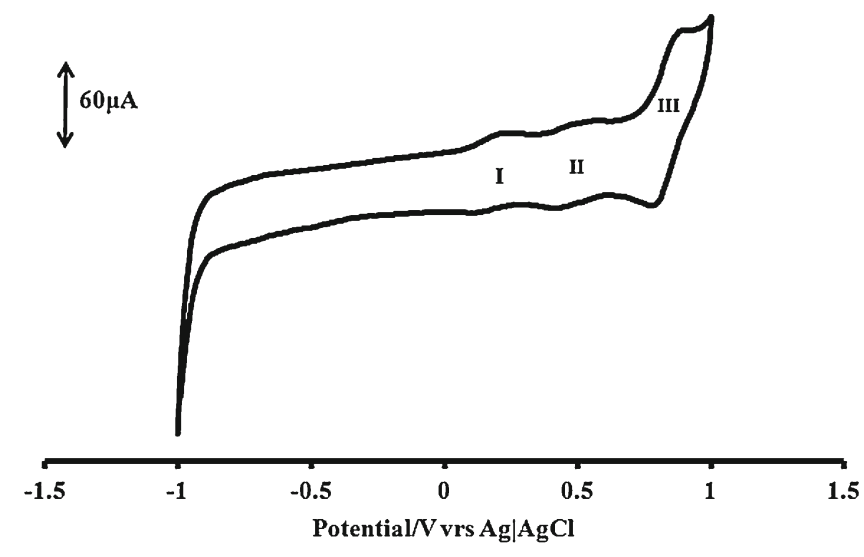

Figure 5. Cyclic voltammogram of $\mathbf{C 3}$ at $1 \times 10^{-3} \mathbf{M}$ in freshly distilled DMF containing $0.1 \mathrm{M} \mathrm{TBABF}_{4}$ as supporting electrolyte. Step potential $=5 \mathrm{mV}$, amplitude $=50 \mathrm{mV}$ vs. $\mathrm{Ag} \mid \mathrm{AgCl}$.

unit. The ${ }^{13} \mathrm{C}$ NMR spectrum shows seven peaks at $\delta 157.42,152.07,138.79,131.26,128.75,125.34$ and $13.94 \mathrm{ppm}$. The carbonyl peak was assigned to the peak at $157.42 \mathrm{ppm}$, the peaks at $152.07,138.79$ and 131.26 are due to the phenanthroline peaks and the two intense peaks at 128.75 and 125.34 are the anthracene peaks. The methyl group was assigned to the peak at $13.94 \mathrm{ppm}$.

\subsection{Cyclic voltammetry studies of complexes}

In the potential range +1.5 to -1.5 at a scan rate $50 \mathrm{mV} \mathrm{s}^{-1}$, the cyclic voltammogram of C2, C3 and C4. (figures 4, 5 and 6), were examined using $\mathrm{Ag} \mid \mathrm{AgCl}$ electrode in DMF solvent with $0.1 \mathrm{M}$ tetra butyl ammonium hexafluorophosphate as supporting electrolyte. The voltammograms display the $\mathrm{Ru}(\mathrm{III}) / \mathrm{Ru}(\mathrm{II})$ couple at positive potentials and the ligand-based reduction couples at negative potentials. The potentials are summarized in table 1. A well-defined reversible peak was observed for $\mathbf{C 2}$ at $0.64 \mathrm{~V}$. This potential was assigned to the $\mathrm{Ru}(\mathrm{III}) / \mathrm{Ru}$ (II) couple. Other ligand-based oxidation potential for $\mathbf{C} 2$ was found at $0.42 \mathrm{~V}$. In the negative potential, $\mathbf{C} 2$ shows reduction potential at -0.62

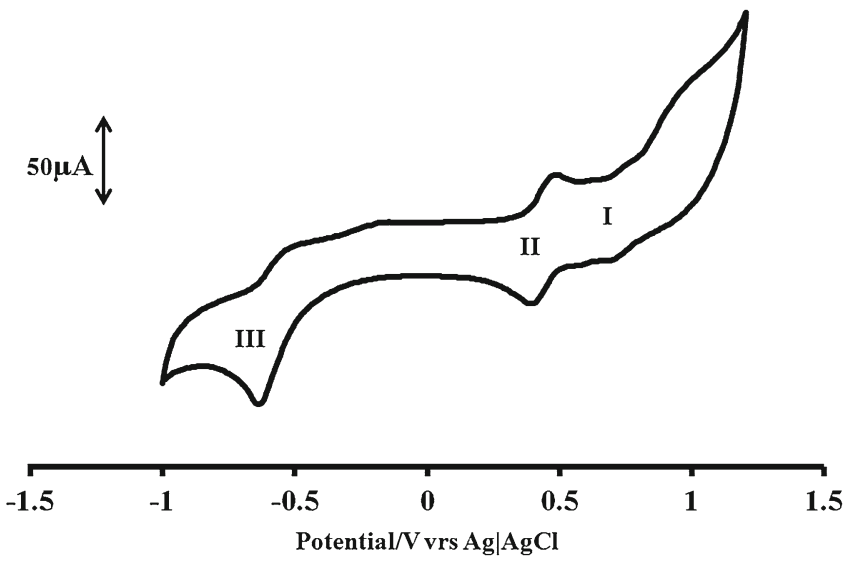

Figure 6. Cyclic voltammogram of $\mathbf{C 4}$ at $1 \times 10^{-3} \mathrm{M}$ in freshly distilled DMF containing $0.1 \mathrm{M} \mathrm{TBABF}_{4}$ as supporting electrolyte. Step potential $=5 \mathrm{mV}$, amplitude $=50 \mathrm{mV}$ vs. $\mathrm{Ag} \mid \mathrm{AgCl}$.

and $-0.99 \mathrm{~V}$. For the derivatized phenanthroline complexes $\mathbf{C 3}$ and $\mathbf{C 4}$, three reversible oxidation processes at $0.15,0.47$ and $0.84 \mathrm{~V}$ were observed for $\mathbf{C 3}$ while C4 shows only one oxidation and/or reduction peak at 0.43 and $-0.58 \mathrm{~V}$, respectively. However, the reduction wave was not well-defined in $\mathbf{C 3}$. Based on the strong negative potential in $\mathbf{C 2}$ compared to $\mathbf{C 3}$, the influence of conjugation is shown, thus giving the support to the increase in number of anthracene molecular unit in the complex and a corresponding increase in its electron donating ability. The cyclic voltammogram of $\mathbf{C 1}$ could not be established based on its poor solubility in solvents.

\subsection{Dye-sensitized solar cells studies}

Application of these complexes in the dye-sensitized solar cells (DSSCs) shows interesting properties, and useful insight into the sensitization of wide-band gap semiconductors by anthracenyl-based molecules was gained. I/V curves for the evaluated complexes C1C4 are displayed for the shunt and series resistance $\left(R_{s h}\right.$ and $\left.R_{s}\right)$. The short circuit currents $\left(J_{s c}\right)$,

Table 1. Summary of the electronic absorption and evaluation of DSSCs characteristics of C1-C4.

\begin{tabular}{lcccccc}
\hline Dye & $\lambda_{\text {abs }}^{a} / \mathrm{nm}\left(\varepsilon / \mathrm{M}^{-1} \mathrm{~cm}^{-1}\right)$ & $\mathrm{J}_{\mathrm{sc}}\left(\mathrm{mA} / \mathrm{cm}^{2}\right)$ & $\mathrm{V}_{\mathrm{oc}} \times 10^{-3}(\mathrm{~V})$ & $\mathrm{P}_{\max }$ & Fill factor $(\mathrm{FF})$ & $(\eta) \%$ \\
\hline C1 & $447(3218)$ & $35.2 \times 10^{-3}$ & -60 & $9.09 \times 10^{-3}$ & $-4.9 \times 10^{3}$ & 0.103 \\
C2 & $447(5770)$ & $\mathrm{ND}$ & $\mathrm{ND}$ & $\mathrm{ND}$ & $\mathrm{ND}$ & $\mathrm{ND}$ \\
C3 & $443(13030)$ & $193.0 \times 10^{-3}$ & -240 & $6.48 \times 10^{-3}$ & $-139.8 \times 10^{3}$ & 0.074 \\
C4 & $452(11556)$ & $9.1 \times 10^{-3}$ & -20 & $121.2 \times 10^{-6}$ & $-13.3 \times 10^{3}$ & 0.001 \\
\hline
\end{tabular}

ND, not determined. 
open circuit potentials $\left(\mathrm{V}_{\mathrm{oc}}\right)$, fill factors $(\mathrm{FF})$ and the conversion efficiencies $(\eta)$ are listed in table 1 . The solar conversion efficiency was calculated using the equation: $\left(\eta=\mathrm{J}_{\mathrm{sc}} \times \mathrm{V}_{\mathrm{oc}} \times \mathrm{FF} / \mathrm{P}_{\text {input }}\right)$, where, $\mathrm{P}_{\text {input }}=$ $0.088 \mathrm{~W}$. Based on the data generated from I/V curves, the DSSCs efficiencies of the molecules show very low overall performance. It was difficult to obtain good films of the $\mathrm{TiO}_{2}$ nanocrystalline semiconductor, and thus a low device resistance, low open circuit voltage, $\mathrm{V}_{\mathrm{oc}}$, and low short circuit current, $\mathrm{I}_{\mathrm{sc}}$ values were obtained. The highest conversion efficiency was recorded for $\mathbf{C 3}(<0.103 \%)$ closely followed by $\mathbf{C 1}$ $(0.074 \%)$. The difference between the performances of the complexes may be attributed to various factors among which include the surface concentrations. The poor absorption of $\mathbf{C 2}$ and $\mathbf{C 4}$ on the semiconductor led to conversion efficiency as low as $0.001 \%$ for $\mathbf{C 4}$. This may be interpreted to result from the bulky anthracenyl groups in the molecules. The bulky sensitizers require more space on the $\mathrm{TiO}_{2}$ surface and penetrate less
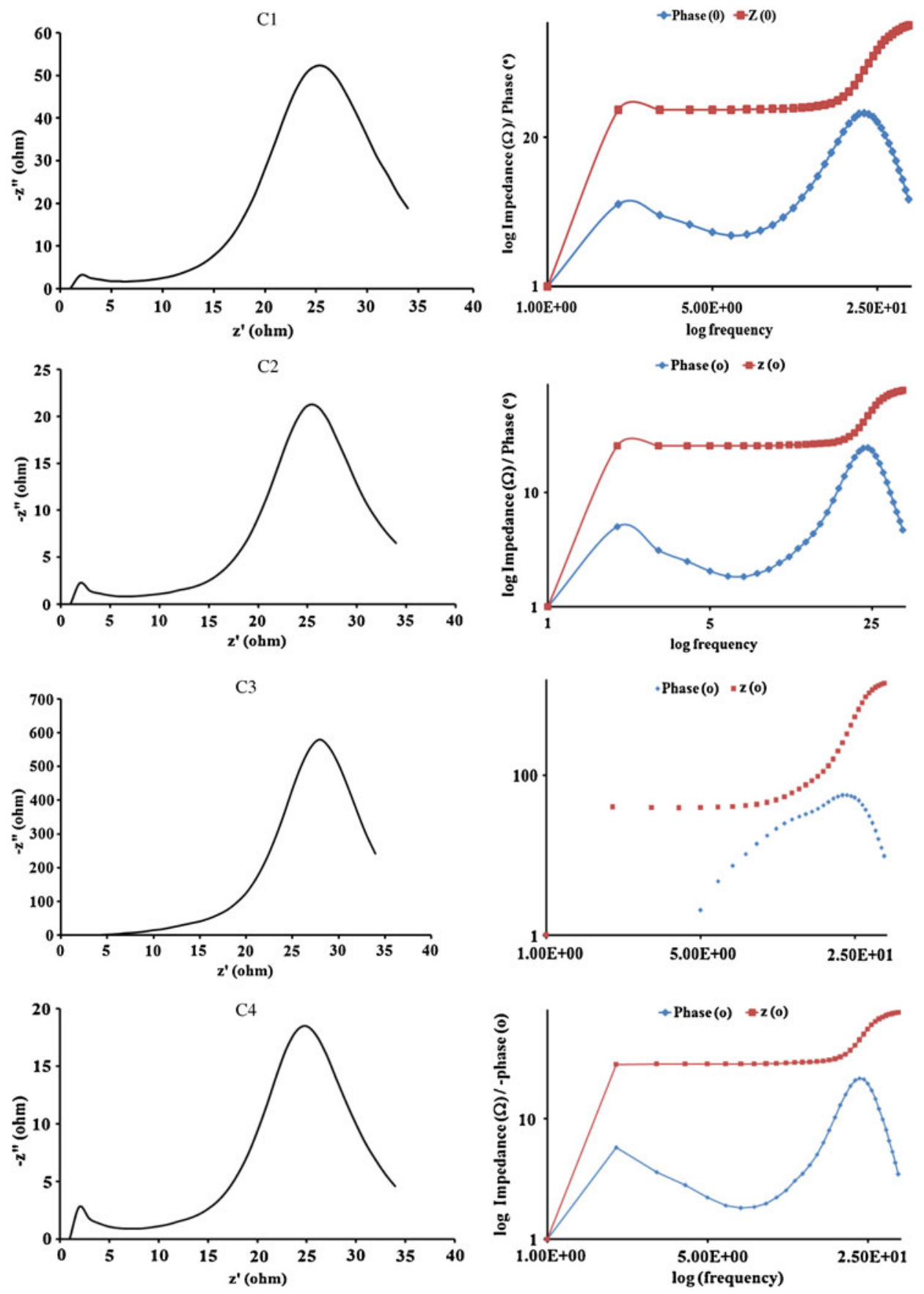

Figure 7. Comparison of Nyquist plots (left) and Bode plots (right) of complexes C1C4 for DSSCs at a constant illumination of $1000 \mathrm{~W} / \mathrm{m}^{2}$. 
easily in the small cavities of the nanocrystalline $\mathrm{TiO}_{2}$ than the sterically less hindered molecules. The effects can be compared with the corresponding ratios of $\mathrm{J}_{\mathrm{sc}}$ values, which range from $4 \%$ to $21 \%$ in the complexes. Here, it is clear that $\mathrm{J}_{\mathrm{sc}}$ depends on the dye surface concentration. Though, it has been reported that ratios are significantly higher than what would be expected if the surface concentration were the only determining factor. ${ }^{38,39} \mathrm{~V}_{\text {oc }}$ was observed to decrease with decrease in surface concentration, in our cells, the low dye coverage has led to lower current output values as could be found in the I/V curves. Indeed, the fitting of the cells I/V characteristics revealed a low $R_{\mathrm{sh}}$, indicative of a high recombination rate at the photoanode surface and high Rs, indicative of the ohmic losses at the counter electrode and the contacts. Although, the tested compounds have appreciable absorption wavelengths in the visible region of absorption for metal-to-ligand charge transfer (MLCT) transitions, the energy difference between the LUMO levels and the $\mathrm{TiO}_{2}$ conduction band could affect the electron injection from the excited dyes. This could be a very significant factor in the overall performance of the DSSCs. Electrolyte leakage was observed during the preparation of the cells, this may have contributed to the low efficiency of the complexes. It is well-known that electrode must be able to transport the charge carrier between photoanode and counter electrode. After the complex injects electrons into the conduction band of $\mathrm{TiO}_{2}$, the oxidized dye must be reduced to its ground state rapidly. The leakage of the electrolyte from the cells may have blocked the smooth transport of the electrons from the complexes to the semiconductor band gap.

\subsection{Electrochemical impedance spectroscopy (EIS) studies}

The impedance analysis of the cell was carried out with an objective to investigate internal resistance of the cell attributable to charge transfer process. The conversion efficiency of the cell can be improved based on the understanding of the charge transfer process and internal resistance of the cell. The components of the DSSC that contributes to impedance are porous $\mathrm{TiO}_{2}$ electrode, counter electrode, and electrolyte. ${ }^{40-42}$ In this work, the analysis was done using both the Nyquist plots and Bode plots (figure 7) which is associated with the different adsorption of complexes on $\mathrm{TiO}_{2}$ semiconductor and was measured at open-circuit voltage. The ohmic serial resistance $\left(\mathrm{R}_{\mathrm{s}}\right)$ corresponds to the electrolyte and the FTO resistance and the resistances $\mathrm{R}_{\mathrm{ct} 2}$ relate to charge-transfer resistance occurring at the dye-sensitized $\mathrm{TiO}_{2}$ film/solution interface. ${ }^{43}$

\section{Conclusion}

The design, synthesis, spectroscopic and electrochemical characterization of a number of new functionalized polypyridine ligands and their corresponding $\mathrm{Ru}(\mathrm{II})$ homonuclear complexes are reported. We further examined the sensitizing properties of the complexes in the dye-sensitized solar cells (DSSCs). Though, it has been established through various studies the importance of visible and or near-infrared absorption, as well as high molar extinction coefficient as parameters important for the enhancement of the solar efficiency of the dye-sensitized solar cells. The main idea in this work has focused on the extension of the $\pi \rightarrow \pi$ conjugation bonds of both the ligands and their corresponding complexes with a view to enhancing the molar absorptivity coefficient.

The complexes reported showed good photophysical and photoluminescence at the visible and near-infrared region of the electromagnetic spectrum. The electroredox properties of complexes showed that they might be useful in the design of chemosensors, photoemitters and other photoelectrochemical processes. Further work is however, necessary to fine-tune the surface morphology of the complexes as well as those for semiconductors to bring about strong adsorption at the interface which would enhance the photon conversion efficiency of the compounds.

\section{Acknowledgements}

We are grateful to the South African National Energy Research Institute (SANERI) and Govan Mbeki Research Centre and University of Fort Hare, Alice, South Africa for financial support. AOA acknowledges Obafemi Awolowo Unversity, Ile-Ife, Nigeria for study leave.

\section{References}

1. Kay A and Grätzel M 1993 J. Phys. Chem. 1176272

2. Nazeeruddin Md K, Humphry-Baker R, Grätzel M and Murrer B A 1998 Chem. Commun. 719

3. Sayama K, Sugino M, Sugihara H, Abe Y and Arakawa H 1998 Chem. Lett. 753

4. Ferrere S, Zaban A and Gregg B A 1997 J. Phys. Chem. $B 1014490$

5. O'Regan B and Grätzel M 1991 Nature 353737

6. Nazeeruddin Md K, Kay A, Rodicio I, Humphry-Baker R, Muller E, Liska P, Vlachopoulos N and Grätzel M 1993 J. Am. Chem. Soc. 1156382

7. Hara K, Sugihara H, Singh L P, Islam A, Kator R, Yanagida M, Sayama K, Murata S and Arakawa H 2001 J. Photochem. Photobiol. A: Chem. 145117 
8. Nazeeruddin Md K, Bessho T, Le Cevey, Ito S, Klein C, De Angelis F, Fantacci S, Comte P, Liska P, Imai H and Grätzel M 2007 J. Photochem. Photobiol. A: Chem. 185 331

9. Pearson P, Bond A M, Deacon G B, Forsyth C and Spiccia L 2008 Inorg. Chim. Acta 361601

10. Funaki T, Yanagida M, Onozawa-Komatsuzaki N, Kawanishi Y, Kasuga K and Sugihara H 2009 Solar Energy Mat. Solar Cells 93729

11. Li C, Yang X, Chen R, Pan J, Tian H, Zhu H, Wang X, Hagfeldt A and Sun L 2007 Solar Energy Mat. Solar Cells 911863

12. Wang X F, Fujii R, Ito S, Koyama Y, Yamano Y, Ito M, Kitamura T and Yanagida S 2005 Chem. Phys. Lett. 4161

13. Song A, Zhang H, Zhang M and Shen T 1999 Dyes Pigments 42149

14. Mosurkal R, He J, Yang K, Samuelson L A and Kumar J 2004 J. Photochem. Photobiol. A 168191

15. Wang P, Zakeeruddin S M, Moser J E, Humphry-Baker R, Comte P, Aranyos V, Hagfeldt A, Nazeeruddin M K and Grätzel M 2004 Adv. Mater. 161806

16. Chen C Y, Wu S J, Wu C G, Chen J G and Ho K C 2006 Angew. Chem. Int. Ed. 455822

17. Yamagushi T, Yanagida M, Kator R, Sugihara H and Arakawa H 2004 Chem. Lett. 33986

18. Goze C, Kozlov D V, Castellano F N, Suffert J and Ziessel R 2003 Tetrahedron 448713

19. Jiang K J, Masaki N, Xia J B, Noda S and Yanagida S 2006 Chem. Commun. 2460

20. Kukrek A, Wang D, Hou Y, Zong R and Thummel R 2006 Inorg. Chem. 4510131

21. Yanagida M, Yamagushi T, Kurashige M, Hara K, Kator R, Sugihara H and Arakawa H 2003 Inorg. Chem. 42 7921

22. Sauve G, Cass M E, Coia G, Doig S J, Lauermann I, Pomykal K E and Lewis N S 2000 J. Phys. Chem. 104 6831

23. Argazzi R, Bignozzi C A, Heimer T A, Castellano F N and Meyer G J 1994 Inorg. Chem. 335741

24. Heimer T A, Heilweil E J, Bignozzi C A and Meyer G J 2000 J. Phys. Chem. A 1044256
25. Polo A S, Itokazu M-K and Iha N Y M 2004 Coord. Chem. Rev. 2481343

26. Ajayagosh A, Carol P and Sreejith S 2005 J. Am. Chem. Soc. 12714962

27. Li Y, Shi L-X, Qin L, Qu L-L, Jing C, Lan M, James T D and Long Y-T 2011 Chem. Commun. 474361

28. Sreejith S, Divya K P, Manojkumar T K and Ajayagosh A 2011 Chem. Asian J. 6430

29. Sreejith S, Divya K P and Ajayagosh A 2008 Chem. Commun. 442903

30. Li Y, Shi L-X, Qin L and Gratzel M 2011 Nano Lett. 11 5501

31. Guo L, Deng J, Zhang L, Xiu Q, Wei G and Zhong C 2012 Dyes Pigm. 921062

32. Vyas P, Bhatt A K, Ramachandraiah $\mathrm{G}$ and Bedekar A V 2003 Tetrahedron Lett. 444085

33. Evans I P, Spencer A and Wilkinson G 1973 J. Chem. Soc. Dalton Trans. 204

34. Mitsopoulou C A, Veroni I, Philippopoulos A I and Falaras P 2007 J. Photochem. Photobiol. A: Chem. 1916

35. Adeloye A O and Ajibade P A 2010 Int. J. Mol. Sci. 11 3158

36. Gunzler $\mathrm{H}$ and Gremlich $\mathrm{H} 2002$ Infrared spectroscopy - An introduction; Weinheim, Germany: WILEY-VCH Verlag GmbA

37. Sun S S and Lees A 2001 J. Inorg. Chem. 3154

38. Ali S, Arta S, Sina H, Siguang C, Pierre G P and Sylvie M 2008 J. New Mat. Electrochem. Systems 11281

39. Ruhle S, Greenshtein M, Chen S G, Merson A, Pizen H, Sukenik S, Cahen D and Zaban A 2005 J. Phys. Chem. B 10918907

40. Hoshikawa T, Kikuchi R and Egushi K 2006 J. Electrochem. Chem. 58959

41. Roy M S, Balraju P, Kumar M and Sharma G D 2008 Sol. Energy Mater. Sol. Cells. 921516

42. Fey G T K, Chen J G, Subramanian V and Osaka T 2002 J. Power Sources 112384

43. Van de Lagemaat J, Park N G and Frank A J $2000 \mathrm{~J}$. Phys. Chem. B. 1042044 